\title{
Length Determination of the Terminal Redundant Regions in the DNA of Phage T7
}

\author{
Brigitte Dreiseikelmann, Ursula Steger, and Wilfried Wackernagel \\ Lehrstuhl Biologie der Mikroorganismen, Ruhr-Universität, D-4630 Bochum, Federal Republic of Germany
}

\begin{abstract}
Summary. The length of the terminal redundant regions in T7 DNA has been determined by two methods. One involved the specific labeling and isolation of the redundant DNA fragment and determination of the molecular weight by polyacrylamide gel electrophoresis. A value of $150 \pm 10$ nucleotide pairs was obtained. The other determination based on a correlation of the melting temperature of the redundant region to that of whole T7 DNA confirmed the result obtained by the first method.
\end{abstract}

The genome of bacteriophage $\mathrm{T} 7$ is a linear DNA duplex of $26 \times 10^{6}$ dalton and has unique terminal redundant regions (TRs; see Studier, 1972). It has been speculated that the TRs play an essential role during the replication of T7 DNA (Watson, 1972). This replication apparently requires formation of linear concatemers (for ref. see Hausmann, 1976) in which unit length molecules are joined together in a head-to-tail fashion by means of the TRs (Watson, 1972; Langman et al., 1978). The length of the TRs has been determined by various techniques, including electronmicroscopy, restriction fragment analysis and biological tests, and the estimates range from 50 to 260 nucleotide pairs (Ritchie et al., 1967; Ludwig and Summers, 1975; Ehrlich et al., 1976; Langman et al., 1978; Dreiseikelmann and Wackernagel, 1978). Here we describe the length determination of the TRs of phage T7 DNA by a method which involves the direct isolation of TRs and which may be generally applied for similar determinations.

Figure 1 outlines the method for the specific labeling and isolation of the TRs. ${ }^{3} \mathrm{H}$-labeled T7 DNA was treated with alkaline phosphatase to remove the terminal 5'phosphate groups. The DNA was then di-

Offprint requests to: Dr. W. Wackernagel gested about $2 \%$ with the $3^{\prime} \rightarrow 5^{\prime}$ exonuclease III of E. coli resulting in single-stranded terminal regions with $5^{\prime} \mathrm{OH}$ ends. The molecules could now be joined together by thermal annealing of the exposed complementary nucleotide sequences of the TRs. After the annealing the $5^{\prime} \mathrm{OH}$ ends were labeled with ${ }^{32} \mathrm{P}$ in a kinase reaction. After removing the ${ }^{32} \mathrm{P}$ label not linked to the DNA by gel chromatography and dialysis, the single-stranded regions flanking the duplex TRs were digested with the single strand-specific S1 endonuclease. In this step the ${ }^{32} \mathrm{P}-$ labeled TRs are released from the concatemers. The total DNA was subjected to polyacrylamide gel electrophoresis followed by autoradiography. We used the fragments of uniformly ${ }^{32} \mathrm{P}$-labeled pBR322 generated by restriction endonuclease Sau3AI (prepared according to Sussenbach et al., 1976) as precise molecular weight markers. Sau3AI cleaves the same nucleotide sequence as $M b o I$, but does this irrespective of adenosylmethylation within this sequence (Sussenbach et al, 1976; Dreiseikelmann et al., 1979). The exact size of these fragments is known from the complete nucleotide sequence of pBR322 (Sutcliffe, 1978). Figure 2 shows the autoradiogram of such a gel and reveals a single DNA band for the TRs corresponding to a size of 150 nucleotide pairs. Control experiments in which Sau3AI fragments of pBR322 were treated with S1 showed that no measurable degradation of duplex DNA by S1 occurred under our conditions (data not shown). We assume that our length determination deviates from the actual length of the TRs by less than \pm 10 nucleotide pairs.

This result was confirmed by an independent procedure which allows to estimate the length of a duplex polynucleotide on the basis of its melting temperature. The correlation between the melting temperature of a given DNA molecule $\left(T_{n}\right)$, the melting temperature of a fragment of this molecule $\left(T_{\mathrm{m}}\right)$ and the length of the fragment measured in nucleotide pairs $(l)$ is 


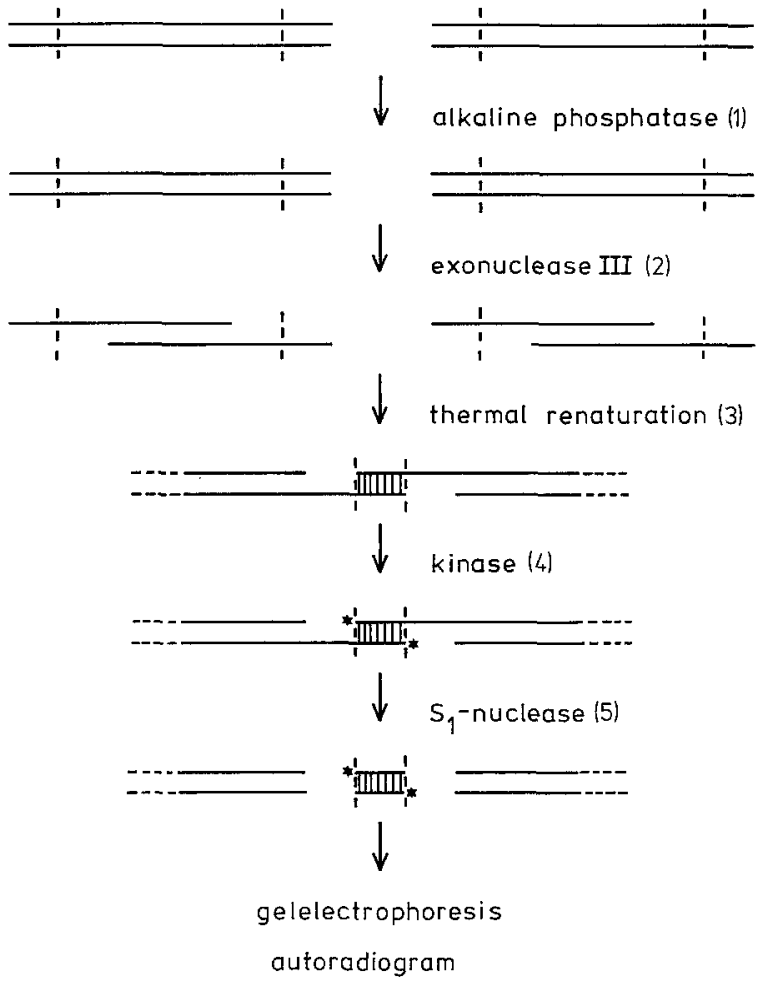

Fig. 1. Method for specific labeling and isolation of the terminal redundant region of the $\mathrm{T} 7$ genome. Numbers refer to the individual steps in the procedure and are detailed below. (1) $0.5 \mu \mathrm{mol}$ of ${ }^{3} \mathrm{H}$-labeled T7 DNA (isolated as described by Seroka and Wackernagel, 1977) were treated for $1 \mathrm{~h}$ at $37^{\circ} \mathrm{C}$ with 10 units of alkaline phosphatase (calf intestine; Boehringer, Mannheim) in $0.5 \mathrm{M}$ Tris$\mathrm{HCl}, \mathrm{pH} 8.0$ followed by phenol extraction. (2) $0.44 \mu \mathrm{mol}$ of the DNA were digested $2 \%$ with 12 units of exonuclease III (isolated according to Richardson et al., 1964) in a reaction mixture of $0.9 \mathrm{ml}$ containing $66 \mathrm{mM}$ Tris- $\mathrm{HCl}, \mathrm{pH} 8.0,0.7 \mathrm{mM} \mathrm{MgCl}_{2}$ and $1 \mathrm{mM} 2$-mercaptoethanol. After incubation at $37^{\circ} \mathrm{C}$ for $10 \mathrm{~min}$ the mixture was heated at $75^{\circ} \mathrm{C}$ for 3 min to inactivate exonuclease III. (3) Annealing of the DNA occurred in kinase buffer (Richardson, 1965) which contained $60 \mathrm{mM}$ Tris- $\mathrm{HCl}, \mathrm{pH} 7.5,10 \mathrm{mM}$ $\mathrm{MgCl}_{2}, 17 \mathrm{mM}$ 2-mercaptoethanol and $1 \mathrm{mM}$ potassium phosphate, $\mathrm{pH} 7.5$. At a DNA concentration of $0.5 \mu \mathrm{mol} / \mathrm{ml}$ the incubation was for $2 \mathrm{~h}$ at $50^{\circ} \mathrm{C}$. (4) The annealed DNA was treated at $37^{\circ} \mathrm{C}$ for $4 \mathrm{~h}$ with 30 units of T4-polynucleotide kinase (Boehringer, Mannheim) in the presence of $80 \mathrm{mM} \gamma^{32} \mathrm{P}$-ATP (specific activity $6.5 \times 10^{6} \mathrm{cpm} / \mu \mathrm{mol}$ prepared according to. Glynn and Chappel, 1964). In order to remove excess of $\gamma-{ }^{32} \mathrm{P}$-ATP the reaction mixture was chromatographed on a column $(15 \mathrm{~mm}$ diameter, $120 \mathrm{~mm}$ length) with Sepharose 4B (Pharmacia). The buffer for equilibration and elution was $5 \mathrm{mM}$ Tris- $\mathrm{HCl}, \mathrm{pH} 7.5,2 \mathrm{mM} \mathrm{NaCl}$. The DNA eluting in the void volume was dialysed for $72 \mathrm{~h}$ against several changes of the elution buffer and was concentrated to $1 \mathrm{ml}$ by evaporation. (5) The sample was adjusted to $30 \mathrm{mM}$ Na-acetate, $\mathrm{pH} 4.5,50 \mathrm{mM} \mathrm{NaCl}$ and $0.3 \mathrm{mM} \mathrm{ZnSO}_{4}$ by adding concentrated stock solutions. Sufficient S1 endonuclease (prepared according to Vogt, 1973) was added to degrade all single-stranded DNA during an incubation of $30 \mathrm{~min}$ at $37^{\circ} \mathrm{C}$

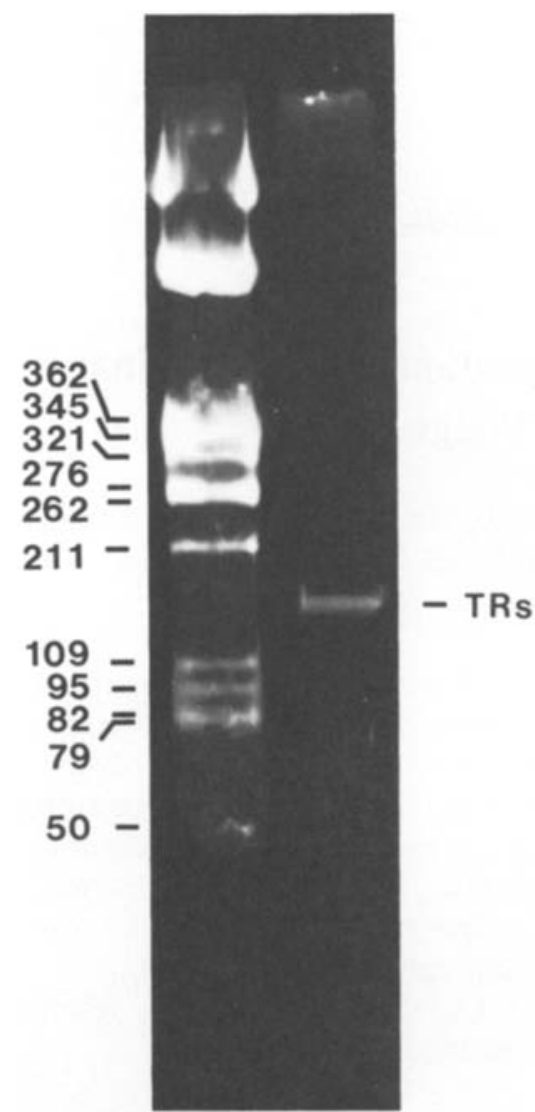

Fig. 2. Autoradiogram after gel electrophoresis of the ${ }^{32} \mathrm{P}$-labeled terminal redundancy (right slot) and fragments of pBR322 generated by Sau3AI (left slot). A $10 \%$ polyacrylamide gel was prepared and run as described (Dreiseikelmann et al., 1979). $40 \mu \mathrm{g}$ of T7 DNA prepared as described in the legend to Fig. 1 were applied to the gel. After electrophoresis the gel was exposed to Kodak Safety Film IRO. The numbers give total nucleotide pairs (including terminal single-stranded tetranucleotides) of uniformly ${ }^{32} \mathrm{P}$ labeled fragments of pBR322

given by $T_{\mathrm{n}}-T_{\mathrm{m}}=B / l$ and has been applied repeatedly (Crothers et al., 1965; Wilson and Thomas, 1974; Britten et al., 1974; Burd et al., 1975). B represents a constant for a given concentration of $\mathrm{Na}^{+}$. In the range between 0.05 and $0.5 \mathrm{M} \mathrm{Na}^{+}$the value of $B$ is given by the equation $B=300+2,000 \times\left[\mathrm{Na}^{+}\right]$(Britten et al., 1974). We applied this method in the following way to determine the length of the TRs. ${ }^{3} \mathrm{H}$ labeled T7 DNA was digested $1 \%$ with the 5 phosphate specific $\lambda$ exonuclease (isolated according to Little et al., 1967) as described (Dreiseikelmann and Wackernagel, 1978) which produced terminal single-stranded tails with $3^{\prime} \mathrm{OH}$ ends. The molecules were thermally annealed into circular and concatemeric structures and subsequently cleaved with Sau3AI. Identical to $M b o$ I, Sau3AI cuts T7 DNA into seven fragments (McDonell et al., 1977). The second and the third largest of these fragments represent the ends of the 


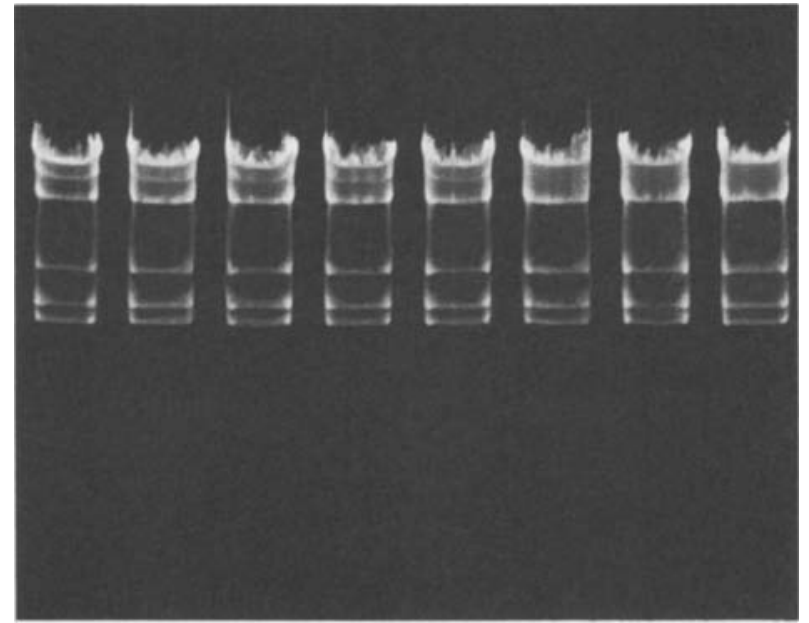

\section{n. h. $83^{\circ} 84^{\circ} 84.5^{\circ} 85^{\circ} 85.5^{\circ} 86^{\circ} 87^{\circ}$}

Fig. 3. Gel electrophoresis of T7 DNA concatemers cleaved by Sau3AI and heated at various temperatures. Concatemers were prepared from $\mathrm{T} 7$ genomes partially digested with $\lambda$ exonuclease as described in the text. After cleavage by Sau3AI samples of the DNA were heated for $3 \mathrm{~min}$ at the temperatures indicated and quickly chilled in ice. Electrophoresis on a $1 \%$ agarose gel was performed as described (Dreiseikelmann et al., 1979). Only the five major fragments of T7 DNA (McDonell et al., 1977) are visible on the gel plus an extra band representing the two terminal fragments joined by hydrogen bonding of the single-stranded TRs (5 slots on the left). n.h. = not heated

T7 DNA molecule. Upon gel electrophoresis of the cleaved concatemers the terminal fragments are joined by the TRs and form an extra band (Fig. 3). The melting of the TRs could thus be followed by observing the separation of the joined fragments by gel electrophoresis after heating of DNA samples at various temperatures. Figure 3 shows that the extra band of the joined fragments virtually disappeared after heating at temperatures of $85.5^{\circ} \mathrm{C}$ or higher indicating that the melting of the TRs is complete at about $85.5^{\circ} \mathrm{C}$ in $0.1 \mathrm{M} \mathrm{Na}^{+}$. For whole T7 DNA molecules this temperature was determined photometrically in a heated cuvette to be $88.5^{\circ} \mathrm{C}$ (not shown). From the difference of $3^{\circ} \mathrm{C}$ between the two melting temperatures we calculated a length of about 170 nucleotide pairs for the TRs. Although the acuracy of this estimation is limited by the rough determination of $T_{\mathrm{m}}$ (Fig. 3) and the use of an empirical formula, the value obtained is in good agreement with that determined in the previous experiment. Our results do not indicate an abnormal low melting temperature of the ends of T7 DNA as was reported earlier (Obel and Freifelder, 1972).

In support of Watson's model we have shown previously that the TRs of T7 DNA are essential for phage production (Dreiseikelmann and Wack- ernagel, 1978). In these experiments it was demonstrated that the removal of 40-80 nucleotide pairs from the ends of T7 DNA molecules destroyed their ability for phage production after transfection. It was concluded that 40 to 80 nucleotide pairs correspond to half the length of the TRs, since removal of half of the TRs or more would leave no overlap of homologous sequences on the molecules for concatemer formation. This functional length determination is consistent with the data reported here.

Acknowledgements. We thank Dr. R. Eichenlaub for critical comments on the manuscript and the Deutsche Forschungsgemeinschaft for support.

\section{References}

Britten, R.J., Graham, D.E., Neufeld, B.R.: Analysis of repeating DNA sequences by reassociation. In: Methods in enzymologie XXIX, part E (L. Grossman and K. Moldave, eds.), pp. 363 418. New York-London: Academic Press 1974

Burd, J.F., Wartell, R.M., Dodgson, J.B., Wells, R.D.: Transmission of stability (telestability) in deoxy ribonucleic acid. J. Biol. Chem. 250, 5109-5113 (1975)

Crothers, D.M., Kallenbach, N.R., Zimm, B.H.: The melting transition of low-molecular-weight DNA: theory and experiment. J. Mol. Biol. 11, 802-820 (1965)

Dreiseikelmann, B., Eichenlaub, R., Wackernagel, W.: The effect of differential methylation by Escherichia coli of plasmid DNA and phage $T 7$ and $\lambda$ DNA on the cleavage by restriction endonuclease MboI from Moraxella bovis. Biochim. Biophys. Acta 562, 418-428 (1979)

Dreiseikelmann, B., Wackernagel, W.: The terminal redundant regions of bacteriophage T7 DNA: their necessity for phage production studies by the infectivity of T7 DNA after modification by various exonucleases. Mol. Gen. Genet. 159, 321-328 (1978)

Ehrlich, S.D., Sagaramella, V., Lederberg, J.: Transfection of restrictionless Escherichia coli by bacteriophage T7 DNA: Effect of in vitro erosion of DNA by $\lambda$ exonuclease. J. Mol. Biol. 105, 603-609 (1976)

Glynn, I.M., Chappel, J.B.: A simple method for the preparation of ${ }^{32} \mathrm{P}$-labeled adenosine triphosphate of high specific activity. Biochem. J. 90, 147-149 (1964)

Hausmann, R.: Bacteriophage T7 genetics. Curr. Top. Microbiol. Immunol. 75, 77-110 (1976)

Langman, L., Paetkau, V., Scraba, D., Miller, R.C., Jr., Roeder, G.S., Sadowski, P.D.: The structure and maturation of intermediates in bacteriophage T7 DNA replication. Can. J. Biochem. 56, 508-516 (1978)

Little, J.W., Lehman, I.R., Kaiser, A.D.: An exonuclease induced by bacteriophage $\lambda$, I. Preparation of the crystalline enzyme. J. Biol. Chem. 242, 672-678 (1967)

Ludwig, A.R., Summers, W.C.: A restriction fragment analysis of the T7 left early region. Virology 68, 360-373 (1975)

McDonell, S.W., Simon, M.N., Studier, F.W.: Analysis of restriction fragments of T7 DNA and determination of molecular weights by electrophoresis in neutral and alkaline gels. J. Mol. Biol. 110, 119-146 (1977)

Richardson, C.C.: Phosphorylation of nucleic acid by an enzyme from T4 bacteriophage-infected E. coli. Proc. Natl. Acad. Sci. U.S.A. 54, 158-165 (1965) 
Richardson, C.C., Lehman, J.R., Kornberg, A. : A DNA phosphatase-exonuclease from $E$. coli. II. Characterization of the exonuclease activity. J. Biol. Chem. 239, 251-258 (1964)

Ritchie, D.A., Thomas, C.A., McHattie, L.A., Wensink, P.C.: Terminal repetition in non-permutated $\mathrm{T} 3$ and $\mathrm{T} 7$ bacteriophage DNA molecules. J. Mol. Biol. 23, 365-376 (1967)

Seroka, K., Wackernagel, W.: In vivo effects of recBC DNase, exonuclease I, and DNA polymerase of Escherichia coli on the infectivity of native and single-stranded DNA of bacteriophage T7. J. Virol. 21, 906-912 (1977)

Studier, F.W.: Bacteriophage T7. Science 176, 367-376 (1972)

Sussenbach, J.S., Monfoort, C.H., Schiphof, R., Stobberingh, E.E.: A restriction endonuclease from Staphylococcus aureus. Nucleic Acids Res. 3, 3193-3202 (1976)
Sutcliffe, J.G.: pBR322 restriction map derived from the DNA sequence: accurate DNA size markers up to 4361 nucleotide pairs long. Nucleic Acids Res. 5, 2721-2728 (1978)

Vogt, V.M.: Purification and further properties of single-strandspecific nuclease from Aspergillus oryzae. Eur. J. Biochem. 33, 192-200 (1973)

Watson, J.D.: Origin of concatemeric T7 DNA. Nature 239, 197201 (1972)

Wilson, D.A., Thomas, C.A., Jr.: Palindromes in chromosomes. J. Mol. Biol. 84, 115-144 (1974)

Communicated by T. Yura

Received November 19, 1979 